\title{
Correlation between CGRP Levels and the Neuropathic and Inflammatory Component of Postoperative Pain
}

\author{
Deyan Neychev ${ }^{1}$, Tanya Sbirkova ${ }^{1}$, Maria Ivanovska ${ }^{2}$, Ralitsa Raycheva ${ }^{3}$, Mariana Murdjeva ${ }^{2}$, \\ Dimitar Atanasov ${ }^{1}$ \\ ${ }^{1}$ Department of Oral Surgery, Faculty of Dental Medicine, Medical University of Plovdiv, Plovdiv, Bulgaria \\ ${ }^{2}$ Department of Microbiology and Immunology, Faculty of Pharmacy, Technological Center of Emergency Medicine, Medical University of Plovdiv, Plovdiv, \\ Bulgaria \\ ${ }^{3}$ Department of Social Medicine and Public Health, Faculty of Public Health, Medical University of Plovdiv, Plovdiv, Bulgaria
}

Corresponding author: Deyan Neychev, Department of Oral Surgery, Faculty of Dental Medicine, Medical University of Plovdiv, 3 Hristo Botev Blvd., 4002 Plovdiv, Bulgaria; E-mail: dneitchev@yahoo.com

Received: 12 Sept 2019 Accepted: 23 Dec 2019 Published: 30 June 2020

Citation: Neychev D, Sbirkova T, Ivanovska M, Raycheva R, Murdjeva M, Atanasov D. Correlation between CGRP levels and the neuropathic and inflammatory component of postoperative pain. Folia Med (Plovdiv) 2020;62(2):365-71. doi: 10.3897/folmed.62.e46533.

\section{Abstract}

Introduction: In surgical procedures, tissue damage results in the release of a number of bioactive substances. Calcitonin gene-related peptide (CGRP) is a peptide released from sensory nerves, which determines its role in pain sensation. Its distribution in tissues determines its role as a primary afferent neurotransmitter.

Aim: To determine the effect of CGRP on postoperative pain and reactive inflammatory process after surgical removal of impacted mandibular third molars, as well as the factors that have influence upon the perception of pain.

Materials and methods: Forty patients with bilaterally impacted mandibular third molars were included in the study. Venous blood samples were collected before and 24 hours after the surgical procedure in order to test their serum levels of CGRP and procalcitonin. Two weeks later the procedure was repeated. The difficulty of the surgical procedure, its duration and complications were assessed in all patients.

Results: The influence of some of the studied factors upon postoperative pain was established. Differences in the sensation of pain between the two sexes were found when comparing pain intensity reported by the patients. Significant difference between pain intensity after the 1st and 2nd surgical procedures (6 hours) was found in females ( $\mathrm{Z}=2.63, p=0.009$;), whereas in males the difference was observed at 24 hours $(\mathrm{Z}=1.99 ; p=0.047)$.

Regarding the existence of sex-related association, a significant, strong positive correlation between CGRP levels after the 1st and 2nd surgical procedures ( 24 hours) was found in males $\left(r_{\mathrm{xy}}=0.78 ; p=0.004\right)$, whereas in females this correlation was also significant, although moderately significant $\left(r_{\mathrm{xy}}=0.44 ; p=0.020\right)$. CGRP levels at the first and second extractions were generally similar in males, and not as much in females. We proved significantly moderate positive association between CGRP and pulse levels measured before the second surgery $\left(r_{\mathrm{xy}}=0.37, p=0.021\right)$.

Conclusion: The results of our study suggest a significant role of CGRP in reactive (neurogenic) inflammation.

\section{Keywords}

calcitonin gene-related peptide, inflammatory pain, neuropathic pain, neuropeptide, pain 


\section{INTRODUCTION}

Postoperative pain management is one of the objectives of scientific research worldwide. In recent years, a number of studies have been conducted in an effort to find substances playing a role in the occurrence, conduction and analysis of pain. ${ }^{1}$ Despite the large number of studies on the mechanisms of pain and its management, the results regarding postoperative pain management are still extremely limited. ${ }^{2}$ Tissue damage during surgical procedures acts as a nociceptive stimulus that triggers the release of primary pain mediators such as prostaglandins, leukotrienes, serotonin and bradykinins. They, in turn, stimulate the release of peptides such as calcitonin gene-related peptide (CGRP) and substance $\mathrm{P}^{3}$ CGRP is a subject of a great number of studies on pain. It is a neurotransmitter belonging to the calcitonin family ${ }^{4}$ and is a 37 -amino-acid neuropeptide which was first identified in rats in $1983^{5}$.

CGRP is secreted primarily from the sensory nerves, which determines its role in pain. ${ }^{6}$ The function and expression of CGRP depend on the site it is produced in. When synthesized by cells located in the dorsal horns of the spinal cord, it plays the role of a pain neurotransmitter. ${ }^{7}$

The concentration of CGRP is the highest in the outer laminae of the dorsal horn and in the trigeminal nucleus caudalis which corresponds to the terminals of primary afferent neurons with soma in the dorsal root ganglion. ${ }^{8}$ Given the tissue distribution of CGRP, a number of authors conclude that it plays a major role as a primary afferent neurotransmitter. ${ }^{9-11}$

Tissue damage, which occurs during surgery, results in releasing of pro-inflammatory mediators - serotonin, histamine, prostaglandins, CGRP, etc. There is growing evidence for an increase in CGRP synthesis during inflammation. ${ }^{12}$ It is considered that when a peripheral terminal of a sensory nerve is activated, the action potential is transmitted not only to the dorsal horn but down the nerve branches as well. This results in the release of neuropeptides from the peripheral branches. Neurogenic inflammation is the term given to the microvascular effects caused by the release of neuropeptides from the periphery of nerve terminals. ${ }^{6}$

The functional relationship between CGRP and pain sensation is of particular interest. ${ }^{7}$ According to Weidner et al. there is no evidence that substance P and CGRP mediate pain directly, they rather contribute to sensitization and pain modulation. ${ }^{13}$ Evidence of the role of CGRP and its relationship with pain is contradictory and is a subject of discussion. ${ }^{14,15}$

In recent years, it has been found that a member of the calcitonin gene family, namely procalcitonin, is one of the most important markers of the severity of the inflammation in the body. ${ }^{16}$ Measuring the levels of this marker would make it possible to determine the significance of the inflammatory process after surgery.

\section{AIM}

The aim of this study was to determine the effect of CGRP on postoperative pain and reactive inflammatory process after surgical removal of impacted mandibular third molars.

\section{MATERIALS AND METHODS}

\section{Participants}

Forty clinically healthy subjects with bilaterally impacted mandibular third molars were included in the study. The mean age of the participants was $22 \pm 3$ years, with the youngest being 18, and the oldest - 40. Informed consent was obtained from all participants, in accordance with the requirements of the Ethics Committee at the Medical University of Plovdiv. The patients were diagnosed by an oral surgeon with bilaterally impacted mandibular third molars, which were to be extracted. Exclusion criteria: allergy to medications, acute inflammation in the area of the tooth to be extracted, regular alcohol consumption or drug abuse, women 5 days before and 5 days after their menstrual period (to exclude the influence of hormonal factors on pain), pregnancy and breastfeeding.

\section{Study design}

The participants were divided, in accordance with the principles of simple randomization, in three groups, depending on the medication they were given preoperatively.

The distribution of medications previously to both surgical procedures was double-blinded and placebo-controlled. The subjects were given a flask with the medication prior to the first surgery. Prior to the second surgery the participants remain unaware whether they received the same drug as the first time. This information was disclosed at the end of the trial. Fifteen participants received ibuprofen 400 mg (1 tablet 3 times a day) - 9 tablets in total, other 15 participants received ibuprofen $400 \mathrm{mg}$ ( 1 tablet 3 times a day) - 9 tablets in total, and gabapentin $300 \mathrm{mg}$ ( 1 tablet in the evening) -3 tablets in total, and the last 10 participants received placebo ( 1 tablet 3 times a day). The time interval between the surgical procedures of each patient was set at two weeks. Prior to the second surgical procedure, each patient received a vial with medication using the principle of simple randomization. Before each surgical procedure, venous blood samples were collected from the patients in order to determine the baseline serum CGRP and procalcitonin levels. Within 24 hours later, intravenous blood samples were collected again in order to monitor the dynamics of the parameters tested. 


\section{Surgical procedure}

The impacted third molars were removed in a surgical procedure at the Department of Oral Surgery of the Medical University of Plovdiv. Half an hour before each procedure, patients received pre-emptively 1 tablet of the medication in the numbered vial which had been given to them. The local anesthetic used in the study was articaine 4\%. A standard surgical technique was applied. The difficulty of the surgical procedure, its duration and complications were assessed in all patients.

\section{Pain scale}

A visual analog scale (VAS) was used to assess postoperative pain. Each patient marked the perceived pain with a vertical check on a $100 \mathrm{~mm}$ ruler, which started at its left end with 0 no pain, and ended at its right end with 10 - very severe pain. Pain was reported at 3, 6, 24, 48 and 72 hours, respectively.

\section{Immunological methods for CGRP and procalcitonin measurement}

To measure serum concentrations of calcitonin gene-related peptide (CGRP), serum was used, which was pre-separated from the blood collected with Vacutainer by centrifugation for 5 minutes at 2,000 rpm. ELISA kit for Human calcitonin gene-related peptide CSB-E08210h was used (Cusabio, USA). Values were obtained by ELISA method (enzyme-linked immunosorbent assay). The procedure was performed according to manufacturer's instructions. Absorption, i.e. optical density, was measured by an ELI$\mathrm{SA}$ reader at a wavelength of $450 \mathrm{~nm}$. Double samples were dropped. By drawing a calibration curve, the concentration of each parameter was determined.

To measure serum concentrations of procalcitonin, enzyme-linked fluorescence assay (ELFA) was used in human serum on VIDAS instruments (bioMérieux, France). VIDAS B.R.A.H.M.S PCT assay is a one-step immunoassay sandwich method with a final fluorescent detection (ELFA). The method used is automated and is extremely sensitive, with limit of quantification (LoQ) of $0.05 \mu \mathrm{g} / \mathrm{L}$ and limit of detection (LoD) of $0.03 \mu \mathrm{g} / \mathrm{L}$.

\section{Statistical analysis}

Numeric variables were presented as mean \pm standard deviation (mean $\pm S D$ ) or median (25th percentile; 75 th percentile), if not normally distributed. Categorical variables were presented as percentage \pm standard error $(\% \pm S E M)$. The difference between two means of dependent samples was tested by paired t-test or Wilcoxon signed ranks test for nonparametric analysis of not normally distributed paired data. A repeated measures ANOVA with a Greenhouse-Geisser correction was applied to follow changes over time. Correlation analysis was performed to study the association between variables, whereas hierarchical multiple regression models were used to examine the relationship between five independent and one dependent variable to isolate predictors which have significant influence on CGRP levels. A p-value $<0.05$ was considered statistically significant for all tests. For the statistical processing we used the data analysis software IBM SPSS Statistics v. 25.

\section{RESULTS}

\section{Assessment of pain duration after surgical procedure}

During the second surgical procedure, two patients dropped out of the study due to their absence. The difficulty of the performed procedures was assessed using the

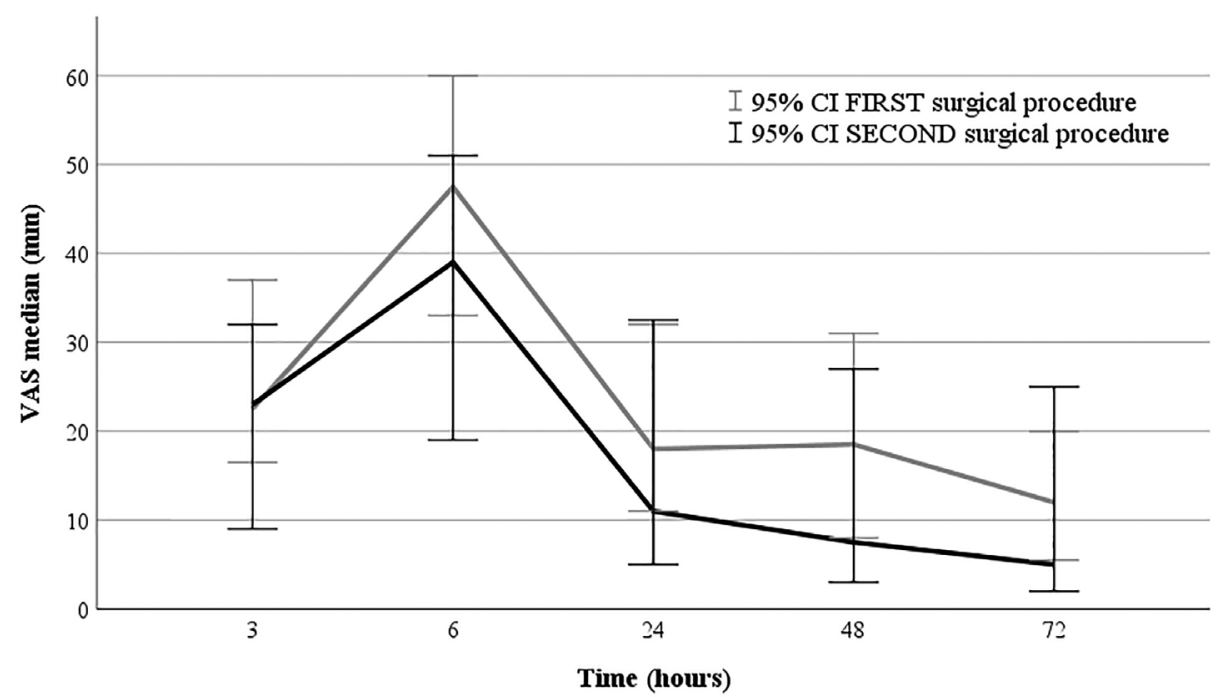

Figure 1. Levels of pain intensity after the surgical procedures at the time points studied.

There was no statistically significant difference in the complications after the two procedures $(p=0.437)$ 
Pederson index. ${ }^{17}$ The first surgical procedure was assessed as difficult in $75 \pm 7 \%$ of the patients, and the second - in $78.8 \pm 1 \%$ of the patients.

The duration of the first surgical procedure was $32 \mathrm{~min}$ (20; $42 \mathrm{~min}$ ), with one significant outlier ( $\mathrm{min}=15 \mathrm{~min}$; $\max =90 \mathrm{~min}$ ). The duration of the second surgery was normally distributed with mean \pm SD time of $35 \pm 13$ minutes.

The average levels of pain intensity assessed by VAS after the second surgical procedure were lower at each of the time points compared to the first procedure, but statistically significant different only at the second time point (at 6 hours $-\mathrm{t}=2.87, p=0.007$ ). The median values follow the same pattern with exception at 3 hours - $23 \mathrm{~mm}(9 ; 44$ $\mathrm{mm})$ vs. $23 \mathrm{~mm}(4 ; 49 \mathrm{~mm})$ (Fig. 1). These data are important in terms of comparison with the results of immunological tests.

\section{CGRP and procalcitonin levels in surgical procedures}

We tested numerous hierarchical multiple regression models with different sets of variables included - duration and difficulty of the second surgical procedure, smoking, complication after the first surgical procedure and the fMRI resting state results after the first and second surgical procedures, which were proven not to influence CGRP level. The models were not significant and the coefficient of determination was below $1 \%$. The only significant model we were able to establish was as follows: a two-block analysis with the CGRP levels reported after the second procedure as a dependent variable:

- Block 1 - in this block we included the predictor which we expected to predict CGRP - the type of medication.

In the next block, we included the explanatory variable (stepwise inclusion), which we did not expect to necessarily have an effect on CGRP, as follows:

- Block 2 - CGRP reported after the first procedure.
In step 1, the application of a hierarchical multiple regression showed that for CGRP measurement after the second procedure, the type of medication did not contribute significantly to the regression model $\mathrm{F}(1,36)=0.03$, $p=0.866$, with determination coefficient of only 0.001 . In Step 2, introducing the variable CGRP reported after the first procedure represents an additional $25 \%$ of variation, and this change in R2 is significant, $\mathrm{F}(2,35)=5.76, p=0.007$. The hierarchical regression analysis with two stages of predictor inclusion allows us to identify which one is significant for the model. First, it is evident from R2 (determination coefficient), signifying the percentage of variation of the variable (CGRP at the second extraction) in response to medication $(0.1 \%)$ and values of CGRP at the first extraction (25\%), i.e. a quarter of the variation of CGRP at second extraction can be explained with the CGRP-values at the first one. Second, it is evident by the significance of the coefficient of the predictor.

The regression coefficient in step 2 b $0=0.20$ (the intercept term in the regression equation), denoted as a constant, is not statistically significant $(\mathrm{t}=0.75, p=0.459)$. The regression coefficient in front of the factor variable medication $\mathrm{b} 1=0.05$ is also not statistically significant $(\mathrm{t}=0.40$, $p=0.690$ ), whereas the regression coefficient in front of the factor variable CGRP after the first procedure b2 $=0.25$ is significant $(\mathrm{t}=3.39, p=0.002)$.

Regarding the existence of sex-related relationship, a significant, strong positive correlation between CGRP levels after the 1 st and 2 nd surgical procedures ( 24 hours) was found in males $\left(\mathrm{r}_{\mathrm{xy}}=0.78 ; p=0.004\right)$, whereas in females this correlation was again significant, but moderate $\left(r_{\mathrm{xy}}=0.44\right.$; $p=0.020)$. CGRP levels at first and second extraction are generally similar in males, and not as much in females.

The repeated measures ANOVA (with the Greenhouse-Geisser correction without taking into account the medications used) did not confirm a statistically significant difference in CGPR levels between the four time points af-

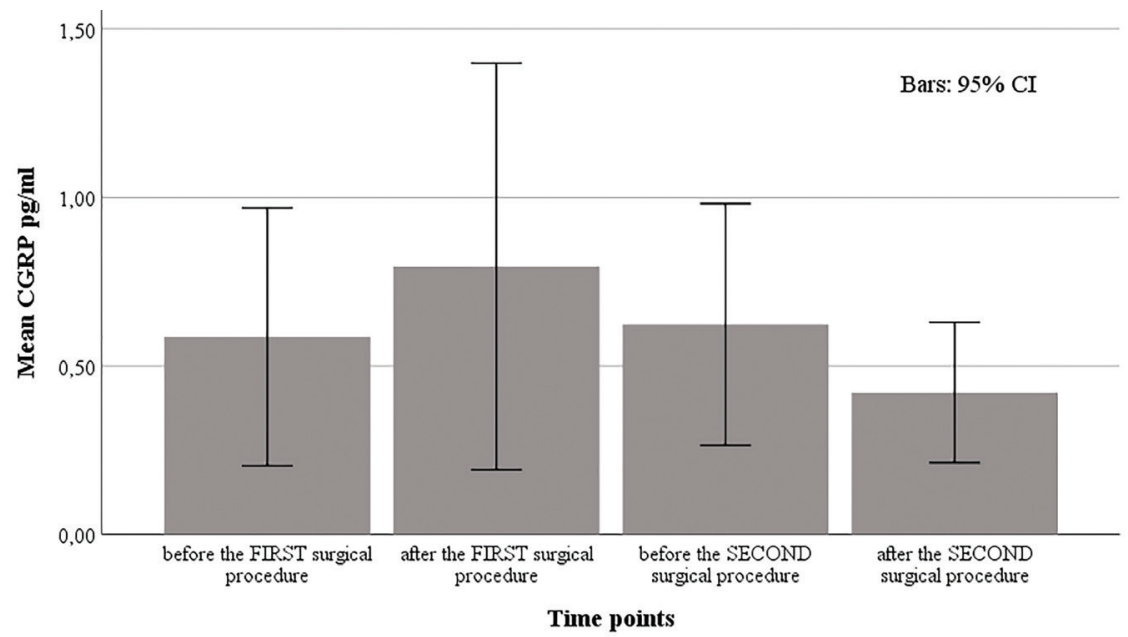

Figure 2. Distribution of CGRP at the four time points studied without taking into account the medication administered. 
ter each surgical procedure as well as in a pairwise comparison (Fig. 2).

We proved significant moderate positive association between CGRP and pulse levels measured before the second surgery $\left(r_{\mathrm{xy}}=0.37, p=0.021\right)$.

The results of the procalcitonin measurements after both surgical procedures showed PCT levels of $<0.5 \mathrm{ng} / \mathrm{mL}$, which indicated possible local inflammation and a local infection with a mild or non-significant systemic inflammatory response.

\section{DISCUSSION}

Understanding the characteristics of postoperative pain is important for its adequate management. ${ }^{18}$ The model used in this study is extraction of impacted mandibular third molars. This model is commonly used in studies of new analgesics as well as in pain-related studies due to the repeatability of relatively identical surgical traumas and the similar intensity of postoperative pain. ${ }^{19-21}$

\section{Characteristics of the surgical proce- dures and subjective assessment of postoperative pain by patients}

The surgical procedures we performed experienced the same difficulty - it is the difficult extraction (by Pederson index), and this makes it possible to compare the results. Another important feature of the surgical procedures is that they were performed in outpatient setting under local anesthesia. This is associated with a serious postoperative pain which was assessed using VAS. The intensity of postoperative pain was highest at 6 postoperative hours, with differences in the results found after the two surgical procedures. Higher intensity was reported after the first surgical procedure $-50 \pm 26$, whereas after the second surgical procedure it was significantly lower $-39 \pm 30$. The results of the assessment of postoperative pain intensity are identical to those found in studies using another model. ${ }^{22}$ Postoperative pain intensity after the second surgical procedure was found to be lower at all time points studied. The probable cause of lower postoperative pain levels after the second surgical procedure, in our opinion, is the cognitive component of pain. Once performed, the surgical procedure is considered as something familiar, which is the reason for the lower pain intensity after the second surgery. No effect of the medications administered on the pain sensation after the surgical procedures was found.

This evidence about the absence of effect of the medication differs from other research in which bilateral impacted mandibular third molars were removed under general anesthesia. Bupivacaine was preemptively infiltrated locally prior to the first extraction, and the second extraction was used as control. The authors reported considerably lower levels of postoperative pain on the side that was treated with bupivacaine. ${ }^{23}$ We speculate that the difference in the reported pain can be explained with the preemptive application of bupivacaine and its long duration (8-12h), which negated the peak of pain, usually experienced at 6 hours post-surgery.

\section{Relationship between postoperative pain characteristics and changes in serum levels of CGRP and procalcitonin}

Postoperative pain has two main components - neuropathic and inflammatory, which largely characterise patient sensations. ${ }^{18}$

Our study did not find a relationship between the medications administered and the serum levels of CGRP. These results are similar to literature data for the absence of correlation between the release of this neurotransmitter and the neuropathic and inflammatory pain. ${ }^{24,25}$

Other studies have found a relationship between neuropathic pain and CGRP release. ${ }^{26}$ In our opinion, the difference in CGRP levels is due to the fact that the study conducted used a model of chronic neuropathic pain. Its characteristics differ significantly from the acute pain resulting from nerve damage due to the surgical procedure.

Studies by some authors have found that CGRP is not an active participant in postoperative pain, but predominantly in inflammatory pain. ${ }^{27}$ According to Bowler et al. ${ }^{28}$, this neuropeptide has multiple functions, and also exhibits anti-inflammatory activity.

The results of our study demonstrate local inflammation and a mild systemic inflammatory response as a result of the surgical procedure, as confirmed by serum procalcitonin levels. The serum levels measured by us are below the widely used limit of $0.5 \mathrm{ng} / \mathrm{mL}$, which is indicative of the presence of inflammation in the early postoperative period. According to some authors, low levels of procalcitonin are indicative of absence of bacteriemia. ${ }^{29}$ This, in our opinion, excludes bacterial genesis of inflammation, but rather makes it neurogenic in nature.

The surgical model we used to investigate CGRP levels allows credibility and comparability of results. Our studies found a moderate correlation between CGRP levels before and after the first, as well as before and after the second surgical procedures. The positive association between serum levels of CGRP and pulse rate prior to the second surgery can be interpreted as confirmation of the above-mentioned hypothesis on the impact of pain's cognitive component. The statistical analysis performed without taking into account the medications used did not demonstrate a statistically significant difference in the results at the four time points. Nevertheless, the graphics of CGRP measurements show a trend to a decrease of the levels of this neurotransmitter before and after the second surgical procedures, which, in our opinion, is a consequence of one of the components of pain that is neglected in some studies - the cognitive component. ${ }^{30,31}$ 


\section{CONCLUSION}

The results of our study suggest a significant role of CGRP in reactive (neurogenic) inflammation. It is advisable to use anti-inflammatory medications in order to manage the inflammatory component of postoperative pain. For greater objectivity of the results, it is necessary to carry out a study with a significantly higher number of patients.

\section{Acknowledgements}

This study was financially supported by a grant SDP-No 10/2017 from the Medical University of Plovdiv.

\section{REFERENCES}

1. Ablin JN, Buskila D, Clauw DJ. Biomarkers in fibromyalgia. Curr Pain Headache Rep 2009;13: 343-9.

2. Takai Y, Yamamoto-Mitani N, Abe Y, et al. Literature review of pain management for people with chronic pain. Jpn J Nurs Sci 2015; 12:167-83.

3. Alcázar-Castro J, Carrillo-Torres O, González-Navarro P. Role of buprenorphine in acute postoperative pain. Rev Med Hosp Gen Méx 2016; 79(3):174-80.

4. Juaneda C, Dumont Y, Quirion R. The molecular pharmacology of CGRP and related peptide receptor subtypes. Trends Pharmacol Sci 2000; 21:432-8.

5. Rosenfeld MG, Mermod JJ, Amara SG, et al. Production of a novel neuropeptide encoded by the calcitonin gene via tissue-specific RNA processing. Nature 1983; 304:129-35.

6. Russell FA, King R, Smillie SJ, et al. Calcitonin gene-related peptide: physiology and pathophysiology. Physiol Rev 2014; 94(4):1099-142.

7. Chen LJ, Zhang FG, Li J, et al. Expression of calcitonin gene-related peptide in ventral and posterior horns of the spinal cord after brachial plexus injury. J Clin Neurosci 2010; 17(1):87-91.

8. Iyengar S, Ossipov MH, Johnson KW. The role of calcitonin generelated peptide in peripheral and central pain mechanisms including migraine. Pain 2017; 158(4):543-59.

9. Mulderry P, Ghatei M, Spokes R, et al. Differential expression of alpha-CGRP and beta-CGRP by primary sensory neurons and enteric autonomic neurons of the rat. Neuroscience 1988; 25:195-205.

10. Amara $S$, Arriza J, Leff $S$, et al. Expression in brain of a messenger RNA encoding a novel neuropeptide homologous to calcitonin generelated peptide. Science 1985; 229:1094-7.

11. Jansen-Olesen I, Mortensen A, Edvinsson L. Calcitonin gene-related peptide is released from capsaicin-sensitive nerve fibres and induces vasodilatation of human cerebral arteries concomitant with activation of adenylyl cyclase. Cephalalgia 1996; 16:310-6.

12. Donnerer J, Stein C. Evidence for an increase in the release of CGRP from sensory nerves during inflammation. Ann NY Acad Sci 1992; 657:505-6.

13. Weidner C, Klede M, Rukwied R, et al. Acute effects of substance P and calcitonin gene-related peptide in human skin-a microdialysis study. J Invest Dermatol 2000; 115: 1015-20.

14. Benemei S, Nicoletti P, Capone JG, et al. CGRP receptors in the control of pain and inflammation. Curr Opin Pharmacol 2009; 9(1):9-14.

15. Naafs MAB. Calcitonin gene related peptide (CGRP) in pain and migraine: a mini-review. Endocrinol Metab Int J 2018; 6(2):130-5.

16. Vijayan AL, Vanimaya, Ravindran S, et al. Procalcitonin: a promising diagnostic marker for sepsis and antibiotic therapy. J Intensive Care 2017; 5:51.

17. Pederson GW. Surgical removal of tooth. In: Pederson GW, editor. Oral surgery. Philadelphia: WB Saunders; 1988. pp 47-81.

18. Pogatzki-Zahn EM, Segelcke D, Schug SA. Postoperative pain-from mechanisms to treatment. Pain Rep 2017; 2(2): e588.

19. Meechan JG, Seymour RA. The use of third molar surgery in clinical pharmacology. Br J Oral Maxillofac Surg 1993; 31(6):360-5.

20. Levrini L, Carraro M, Rizzo S, et al. Prescriptions of NSAIDs to patients undergoing third molar surgery : an observational, prospective, multicentre survey. Clin Drug Investig 2008; 28(10):657-68.

21. Araújo RZ, Pintor Junior AAC, Sigua-Rodriguez EA, et al. Pain control in third molar surgery. Int J Odontostomat 2016; 10(3):385-91.

22. Moiniche S, Dahl JB, Erichsen CJ, et al. Time course of subjective pain ratings, and wound and leg tenderness after hysterectomy. Acta Anaesthesiol Scand 1997; 41:785-9.

23. Nayyar MS, Yates C. Bupivacaine as pre-emptive analgesia in third molar surgery: Randomised controlled trial. Br J Oral Maxillofac Surg 2006; 44(6):501-3.

24. Schou WS, Ashina S, Amin FM, et al. Calcitonin gene-related peptide and pain: a systematic review. J Headache Pain 2017; 18(1):34.

25. Zagólski O, Gajda M, Stręk P, et al. Adult tonsillectomy: postoperative pain depends on indications. Braz J Otorhinolaryngol 2016; 82:589-95.

26. Kalliomäki M, Kieseritzky JV, Schmidt R, et al. Structural and functional differences between neuropathy with and without pain? Exp Neurol 2011; 231(2):199-206.

27. Ishida K, Kawamata T, Tanaka S, et al. Calcitonin gene-related peptide is involved in inflammatory pain but not in postoperative pain. Anesthesiology 2014; 121(5):1068-79.

28. Bowler KE, Worsley MA, Broad L, et al. Evidence for anti-inflammatory and putative analgesic effects of a monoclonal antibody to calcitonin gene-related peptide. Neuroscience 2013; 228:271-82.

29. Hoeboer SH, van der Geest PJ, Nieboer D, et al. The diagnostic accuracy of procalcitonin for bacteraemia: a systematic review and metaanalysis. Clin Microbiol Infect 2015; 21(5):474-81.

30. Moriarty O, McGuire BE, Finn DP. The effect of pain on cognitive function: a review of clinical and preclinical research. Prog Neurobiol 2011; 93(3): 385-404.

31. Moreira SA, Novak P. Effects of pain on cognitive function and mobility. Open Access Journal of Clinical Trials 2019:11:1-10. 
Корреляция между уровнями CGRP и невропатическим воспалительным компонентом
послеоперационной боли

Деян Нейчев ${ }^{1}$, Таня Сбиркова ${ }^{1}$, Мария Ивановска ${ }^{2}$, Ралица Райчева ${ }^{3}$, Мариана Мурджева $^{2}$, Димитр Атанасов ${ }^{1}$

${ }^{1}$ Кафедра хирургической стоматологии, Факультет дентальной медицины, Медицинский университет - Пловдив, Пловдив, Болгария

${ }^{2}$ Кафедра микробиологии и иммунологии, Факультет фармации, Технологический иентр неотложной медицины, Медицинский университет Пловдив, Пловдив, Болгария

${ }^{3}$ Кафедра соииальной медицинь и общественного здравоохранения, Факультет общественного здравоохранения, Медииинский университет - Пловдив, Пловдив, Болгария

Адрес для корреспонденции: Деян Нейчев, Кафедра хирургической стоматологии, Факультет дентальной медицины, Медицинский университет - Пловдив, бул. „Христо Ботев“ № 3, 4002 Пловдив, Болгария; E-mail: dneitchev@yahoo.com

Дата получения: 12 сентября 2019 Дата приемки: 23 декабря 2019 Дата публикации: 30 июня 2020

Образец цитирования: Neychev D, Sbirkova T, Ivanovska M, Raycheva R, Murdjeva M, Atanasov D. Correlation between CGRP levels and the neuropathic and inflammatory component of postoperative pain. Folia Med (Plovdiv) 2020;62(2):365-71. doi: 10.3897/ folmed.62.e46533.

\section{Резюме}

Введение: При хирургических вмешательствах повреждение тканей приводит к выделению ряда биологически активных веществ. Кальцитонин-ген-связанный пептид (CGRP) представляет собой пептид, высвобождаемый сенсорными нервами, который определяет его роль в ощущении боли. Его распределение в этих тканях определяет его роль в качестве первичного афферентного нейротрансмиттера.

Цель: Определить влияние CGRP на послеоперационную боль и реактивный воспалительный процесс после хирургического удаления поражённого третьего моляра нижней челюсти, а также факторы, влияющие на ощущение боли.

Материалы и методы: В исследование было включено 40 пациентов с двусторонним поражением третьего моляра нижней челюсти. Образцы венозной крови отбирали до и через 24 часа после операции для определения уровня CGRP в сыворотке и уровней прокальцитонина. Через две недели процедуру повторили. Сложность хирургического вмешательства, его продолжительность и осложнения были оценены для всех пациентов.

Результаты: Установлено влияние некоторых из изученных факторов на послеоперационную боль. Различия в болевых ощущениях между полами были обнаружены при сравнении интенсивности боли, сообщаемой пациентами. Значительная разница между интенсивностью боли после первой и второй хирургической процедуры (6 часов) была обнаружена у женщин $(\mathrm{Z}=2.63, \mathrm{p}=0.009 ;)$, тогда как у мужчин разница наблюдалась через 24 часа. $(\mathrm{Z}=1.99 ; \mathrm{p}=0.047)$.

Что касается гендерной ассоциации, у мужчин была обнаружена значительная, сильная положительная корреляция между уровнями CGRP после первой и второй хирургической процедуры (24 часа) $\left(\mathrm{r}_{\mathrm{xy}}=0.78 ; \mathrm{p}=0.004\right)$, в то время как у женщин эта корреляция также была значительной, но умеренно значимой $\left(\mathrm{r}_{\mathrm{xy}}=0.44 ; \mathrm{p}=0.020\right)$. Уровни CGRP при первом и втором экстракциях были в целом одинаковыми у мужчин, но не так сильно выражены у женщин. Мы продемонстрировали значительную умеренную положительную связь между CGRP и частотой сердечных сокращений, измеренными перед второй операцией $\left(\mathrm{r}_{\mathrm{xy}}=0.37, \mathrm{p}=0.021\right)$.

Заключение: Результаты нашего исследования показывают значительную роль CGRP в реактивном (нейрогенном) воспалении.

\section{Ключевые слова}

кальцитонин-ген-связанный пептид, воспалительная боль, невропатическая боль, нейропептид, бол 